\title{
Nitrogen removal from landfill leachate in constructed wetlands with reed and willow: Redox potential in the root zone
}

\author{
Andrzej Białowiec $^{\mathrm{a}, *}$, Laura Davies ${ }^{\mathrm{b}}$, Antonio Albuquerque ${ }^{\mathrm{c}}$, Peter F. Randerson ${ }^{\mathrm{b}}$ \\ ${ }^{a}$ University of Warmia and Mazury in Olsztyn, Department of Environmental Biotechnology, ul. Sloneczna 45 G, 10-900 Olsztyn, Poland \\ ${ }^{\mathrm{b}}$ School of Biosciences, Cardiff University, Cardiff CF10 3AX, UK \\ ${ }^{\mathrm{c}}$ Department of Civil Engineering and Architecture, University of Beira Interior, Edificio 2 das Engenharias, Calcada Fonte do Lameiro, 6201-001 Covilha, Portugal
}

\section{A R T I C L E I N F O}

\section{Article history:}

Received 30 July 2010

Received in revised form

16 May 2011

Accepted 25 November 2011

Available online 24 December 2011

\section{Keywords:}

Landfill leachate

Constructed wetland

Redox potential

Nitrogen removal

\begin{abstract}
A B S T R A C T
This study investigated the effects of reed and willow on bioremediation of landfill leachate in comparison with an unplanted control by measuring redox potential levels in the rhizosphere of microcosm systems in a greenhouse. Plants had a significant influence on redox potential relative to the plant-less system. Redox potential in the reed rhizosphere was anoxic (mean $-102 \pm 85 \mathrm{mV}$ ), but it was the least negative, being significantly higher than in the willow (mean $-286 \pm 118 \mathrm{mV}$ ), which had the lowest Eh. Redox potential fluctuated significantly in the willow rhizosphere during daylight hours, with large decreases in the morning. Levels of $\mathrm{NH}_{4}^{+}$decreased significantly in the first day of the experiment and remained at similar low levels in all three variants for the next four weeks of the experiment. Following this removal of ammonia significant peaks in $\mathrm{NO}_{2}^{-}$occurred in the control and reed tanks on the 1st day, and again on 14th day in the control tank up to $13 \mathrm{mg} / \mathrm{dm}^{3}$. In the willow tank there was also one significant peak of $\mathrm{NO}_{2}^{-}$in the first week, but only up to $0.5 \mathrm{mg} / \mathrm{dm}^{3}$. Significant accumulation, within 21 days of $\mathrm{NO}_{3}^{-}$in all variants was observed, but in tanks with reed and willow the concentration of $\mathrm{NO}_{3}^{-}$ remained significantly lower $\left(<4 \mathrm{mg} / \mathrm{dm}^{3}\right)$ than in the unplanted tank $\left(\sim 35 \mathrm{mg} / \mathrm{dm}^{3}\right)$. Final levels of total-nitrogen, nitrate and chemical oxygen demand were considerably lower in the reed and willow tank than in the unplanted tank.
\end{abstract}

(c) 2011 Elsevier Ltd. All rights reserved.

\section{Introduction}

Treatment of LL normally uses high-tech solutions (e.g. activated sludge followed by reverse osmosis, ultrafiltration or ozonation) that present high operation and maintenance costs and, therefore, are not sustainable at many landfill sites, especially in rural areas. The use of ecological systems such as constructed wetlands (CW) has been seen as an economical and technically sustainable solution for LL treatment making it safe to discharge into the environment (Christensen et al., 1992; Schnoor et al., 1995).

Plants commonly used in constructed wetlands include: cattail (Typha latifolia L.), reed (Phragmites australis Trin ex Steudel), rush (Juncus effusus L.), yellow flag (Iris pseudacorus L.), and mannagrass (Glyceria maxima). As well as these typical natural wetlands plant species, willow (Salix sp.) may be used in constructed wetlands with high efficiency. Constructed wetlands (CW) with reed (Wojciechowska and Obarska-Pempkowiak, 2008; Wojciechowska et al., 2009) as well with willow (Białowiec et al., 2007; Randerson,

\footnotetext{
* Corresponding author. Tel./fax: +48 895234131.

E-mail addresses: andrzej.bialowiec@uwm.edu.pl (A. Białowiec), ajcalb@ netvisao.pt (A. Albuquerque), randerson@cardiff.ac.uk (P.F. Randerson).
}

2006) have been shown to be effective in the removal of high levels of ammonia and total nitrogen (TN) from LL. A review of the potential for the use of willow filter beds and Short Rotation Plantations to treat LL by Duggan (2005) concluded that several studies showed success of willow filter beds in treating LL and that treatment improved with the number of the willows.

Oxygen released from roots creates aerobic conditions in the otherwise anaerobic rhizosphere, which induces growth of both heterotrophic and autotrophic aerobic bacteria (nitrifiers) and the aerobic breakdown of organic material (Brix, 1997). Enough oxygen is available in the root zone for respiration and release into the rhizosphere for the formation of an oxidative protective film around the root surface. Enhanced nitrification by microorganisms in the oxygenated rhizosphere is an important process in the treatment of LL with high levels of $\mathrm{NH}_{4}$. Removal of ammonia through nitrification is advantageous not only because it helps in the removal of $\mathrm{N}$ loads, but also because the end $\mathrm{N}$ specie $\left(\mathrm{NO}_{3}^{-}\right)$is much less toxic and more bioavailable to plants than $\mathrm{NH}_{4}^{+}$(Jones et al., 2006). Plant uptake also plays an important role in the enhancement of $\mathrm{N}$ removal, especially in treatment wetlands containing fast-growing plants such as willows (Randerson, 2006). In addition, plants can facilitate removal of $\mathrm{N}$ from wetlands by microbial activity. Organic 